measures. The ICJ, for example, has traditionally been cautious in this respect, having so far not gone beyond rebuking counsel for unduly delaying the proceedings, ${ }^{10}$ and disregarding untruthful evidence without reproaching counsel. ${ }^{11}$ In interstate proceedings, such restraint in regulating counsel conduct and sanctioning misbehavior is generally appropriate as counsel behavior, more often than not, will be a reflection of the state party's instruction, rather than counsel's independent course of action. Moreover, in the absence of compulsory jurisdiction, an international court or tribunal must navigate the fine line between exercising its judicial function independently of the state parties before it, while maintaining states' willingness to submit future disputes to international dispute settlement.

The attitude of the court or tribunal should, however, change if more and more private attorneys start acting as counsel in international proceedings, as already is the case in investment treaty arbitration, and start developing behavior that is independent of state instructions and prejudices not only the integrity of the proceedings, but has the potential to cause detriment to the party represented. In such cases, a duty of the court or tribunal may kick in to address unethical counsel behavior more actively and through formal means. For this purpose, international courts and tribunals should be cognizant of the powers to regulate counsel conduct and to sanction breach, which are expressly given to them in their founding statutes or conferred upon them as a matter of inherent necessity, and make use of them in order to ensure the fair, efficient and legitimate administration of international justice.

\title{
Fraudulent Evidence at the International Court of Justice
}

\section{By Cecily Rose}

This contribution begins by considering the problem of fraudulent evidence at the International Court of Justice (ICJ or Court) from the perspective of the opposing party-that is, the party that receives rather than submits the suspect evidence. In particular, what factors might motivate the opposing party to challenge documentary submissions as false, or to refrain from doing so? This contribution then considers how the ICJ should respond to such allegations of fraud, and whether it has any obligations to raise concerns about fraud proprio motu.

\section{Fraudulent Evidence from the Perspective of an Opposing Party}

In considering whether to challenge the authenticity of documentary submissions, an opposing party could view this problem not only from the standpoint of legal ethics, but also from the standpoint of litigation strategy. Neither perspective is governed by international legal rules, due the absence of binding ethics rules for counsel appearing before the ICJ, and the fact that the ICJ's Rules of Court and Practice Directions do not address such issues. But the International Law Association's Hague Principles on Ethical Standards for Counsel

\footnotetext{
${ }^{10}$ See Shabtai Rosenne, The Law and Practice of the International Court 542 (2d ed. 1985) (referencing Corfu Channel, Pleadings, Vol. III, at 187-88). See also Application of the Convention on the Prevention and Punishment of the Crime of Genocide (Bosn. \& Herz. v. Serb. \& Montenegro), Provisional Measures, Order, 1993 ICJ Rep. 325, 336-37, para. 21 (Sept. 13).

${ }^{11}$ See Keith Highet, Evidence, the Chamber and the ELSI Case, in FACT-FIndING Before International Tribunals 33, 65-68 (Richard Lillich ed, 1992); Elettronica Sicula (U.S. v. It.), Judgment, 1989 ICJ Rep. 15, para. 26 (July 20); W. Michael Reisman \& Christina Parajon Skinner, Fraudulent Evidence Before Public International Tribunals: The Dirty Stories of International LaW 54-77, 163-92 (2014).

* Assistant Professor, Grotius Centre for International Legal Studies, Leiden Law School.
} 
Appearing Before International Courts and Tribunals (The Hague Principles) may nevertheless provide useful guidance.

From the perspective of litigation strategy, an opposing party may have everything to gain by seeking to exclude fraudulent evidence that falsely and unfairly strengthens the other party's case. But a decision by an opposing party to challenge the authenticity of the other party's documentary submissions could run the risk of drawing attention to its own submissions, which could also be of questionable authenticity. This consideration will, of course, not play a role where the opposing party has complete certainty of the authenticity of its own submissions. External counsel may, however, have their doubts in situations where they have simply been presented by their client with a voluminous set of purportedly authentic documents from government archives. External counsel may have little capacity to assess the authenticity of such documents themselves, without the help of historians, linguists, or forensic experts. Thus, in raising questions about possible forgery, an opposing party could inadvertently prompt questions about its own submissions, some of which could also be fraudulent. Such a challenge could, at least in theory, attract increased scrutiny by both parties and the Court itself of the entire documentary record in the case at hand.

The likelihood that a challenge by an opposing party would result in greater scrutiny of its own documents by the other party will depend in part on the other party's capacity and willingness to devote financial resources to retaining external forensic experts. In Maritime Delimitation and Territorial Questions Between Qatar and Bahrain (Qatar v. Bahrain), for instance, Bahrain retained leading historians and forensic experts to analyze documents submitted by Qatar. ${ }^{1}$ But not all disputing parties before the ICJ may be willing or able to go so far, particularly in smaller-scale instances of possible forgery.

In addition, the Court itself may be relatively unlikely to respond to such a challenge by undertaking an examination of both parties' documents-either on its own, or with the help of experts. In general, the Court takes a relatively passive stance with respect to many evidentiary matters. Although nothing prevents the Court from investigating the authenticity of submitted documents, it appears to have no history of doing so. Instead, the Court tends to depend on the parties to provide authentic, relevant evidence, with little interference or direction from the bench.

Thus, on the one hand, an opposing party may have an interest in not drawing any unnecessary attention to the authenticity of the annexes it has submitted to the Court. On the other hand, the risks involved in calling attention to its own annexes might be outweighed by the advantages to be gained from having the other party's fraudulent documents excluded by the Court. In making this assessment, the scale of the suspected forgery and the importance of excluding the documents from the Court's record may be important considerations for the opposing party.

From the perspective of legal ethics, counsel for an opposing party are not bound by any legal obligation to challenge the other party's documentary evidence in instances of suspected fraud. The ICJ's Practice Directions for states appearing before it make no mention of issues regarding the authenticity of evidence and what might be done in situations of suspected fraud. Principle 3.2 of The Hague Principles does, however, provide that counsel shall not advise or assist a client to engage in conduct that he or she knows or ought to know is fraudulent. But this Principle does not extend to counsel's knowledge or suspicion of the

\footnotetext{
${ }^{1}$ W. Michael Reisman \& Christina Parajon Skinner, Fraudulent Evidence Before Public International Tribunals: The Dirty Stories of International LaW 179, 191 (2014).
} 
other party's fraudulent conduct. These Principles therefore may not be seen as generating any expectation that counsel for an opposing party would challenge or draw attention to the other party's potentially fraudulent documents. General concerns about the integrity of the dispute settlement process at the Court might prompt counsel for an opposing party to challenge the authenticity of evidence that might impact the factual accuracy of the record before the Court. But as Michael Reisman and Catherine Skinner have shown, counsel in such situations have tended to be loyal, first and foremost, to their clients (the litigating states), while concerns about the integrity of the Court's factual record have assumed a secondary importance. ${ }^{2}$

\section{Fraudulent Evidence from the Perspective of the Court}

Should an opposing party refrain from challenging the other party's documentary evidence, the Court might be faced with a decision about whether or not to consider the matter itself, proprio motu. The Court has no independent obligation to investigate suspicious evidence not formally challenged by one of the parties. Neither the Statute nor Rules of Court oblige the Court to raise questions about fraudulent or forged evidence, and in general, these instruments are vague with respect to evidentiary matters. This is not surprising given that the Committee of Jurists, which drafted the Statute of the Permanent Court of International Justice (which forms the basis for the ICJ's Statute), was focused less on procedural or evidentiary issues, and more on fundamental issues concerning the Court's competency and composition.

But the ICJ Statute and the Rules of Court do not leave the Court powerless in situations of fraud-the Court does, in fact, have the capacity to take measures if it suspects fraud. Articles $48-50$ of the Court's Statute, for example, would allow it to verify the authenticity of evidence by asking the party that produced the suspect evidence to provide explanations, and by retaining its own experts to examine the evidence. These options would, however, require the Court (or a member of the Court) to have thoroughly examined the annexes to the parties' pleadings well before the oral hearings, in order to allow sufficient time for such explanations or expert reports. This may not be realistic given the Court's working methods, and its general reluctance to actively direct the parties with respect to evidentiary matters.

Finally, should an opposing party decide to challenge the authenticity of the other party's documentary evidence, the Court would then be faced with decisions about how to respond. In Qatar v. Bahrain, the Court adopted a notably passive role at this stage. ${ }^{3}$ After Bahrain challenged the authenticity of eighty-one documents annexed to Qatar's Memorial, the Court did not immediately require Qatar to respond to this challenge, nor did it rule on the matter. ${ }^{4}$ Moreover, Qatar continued to rely on the challenged documents in a subsequent written pleading. ${ }^{5}$ The Court later required Qatar to submit an interim report on the matter. ${ }^{6}$ In this report, which Qatar submitted more than a year after Bahrain had raised its challenge, Qatar indicated that it had decided to disregard the challenged documents. ${ }^{7}$ At this point, the Court did not issue a ruling excluding the documents from the record. Instead, the Court effectively

${ }^{2}$ Id. at $8-9$.

${ }^{3}$ Maritime Delimitation and Territorial Questions Between Qatar and Bahrain (Qatar v. Bahr.), Merits, Judgment, 2001 ICJ Rep. 40, paras. 15-23 (Mar. 16).

${ }^{4} I d$., paras. $15-16$.

${ }^{5}$ Id. , para. 18.

${ }^{6} I d$., para. 19.

${ }^{7}$ Id., para. 20. 
left it to the parties to reach an understanding on how to proceed. ${ }^{8}$ Bahrain led the way: it responded to Qatar's report by noting that Qatar had abandoned the "impeached documents," and it concluded that Qatar could not make any further reference to them and that the Court would adjudicate the merits of the case without regard to them. ${ }^{9}$ Qatar subsequently expressed its regret about the situation-thus seemingly accepting this outcome. ${ }^{10}$ In a subsequent procedural order, the Court adopted the understanding reached by the parties. ${ }^{11}$ The judgment on the merits merely recounts this procedural history, without mentioning the words "fraud" or "forged," and without reprimanding Qatar. ${ }^{12}$

Had the Court taken a more active approach to this matter, it might have disposed of Bahrain's challenge more expediently, and with greater force-it might have sent a warning to future litigants before the Court about the repercussions of fraudulent evidence. In future cases, the Court might consider taking a more active stance by requiring both parties to file reports on the authenticity of challenged evidence before either party submits any further pleadings. In addition to reports submitted by the parties, the Court could also hire its own historians and/or forensic experts to assess the authenticity of challenged evidence. Ideally, the Court would do so in a transparent manner, by formally appointing an expert under Article 50 of the Statute - a procedure which would allow the parties to review and comment on any expert reports. ${ }^{13}$ On the basis of these expert reports, the Court would then rule on the authenticity of the challenged evidence and formally decide whether to exclude it from the evidentiary record. In Qatar v. Bahrain, by contrast, the Court left it to the parties to reach a mutually acceptable understanding, and it never formally excluded the evidence from the record or reprimanded Qatar.

The Court's traditionally deferential or diplomatic attitude toward litigants as sovereign states may make it reluctant to publicize misconduct by parties, or to rebuke them for it. But as a permanent judicial institution, the Court may have an interest in making its procedures in cases of suspected fraud more formal and transparent. Should concerns about the authenticity of evidence arise in the future, the Court might adopt more formal and transparent measures with a view toward deterring future litigants from submitting fraudulent documents, and encouraging counsel to exercise greater scrutiny-to the extent possible.

\section{Summary by Douglas Cantwell*}

Approximately eighty people attended the Roundtable. ASIL President Lori Damrosch began the session, reflecting on Professor Vagts' work and her admiration for him as a scholar, mentor, colleague, and friend. Professor Damrosch's introduction was followed by remarks from Karen Vagts, who offered personalized reflections on her father's life and work. The Roundtable's Convener, Professor Catherine Rogers of Penn State School of Law, reflected on working with Professor Vagts as a younger scholar. During these introductory

\footnotetext{
${ }^{8} I d$., para. 23.

${ }^{9}$ Id., para. 20

${ }^{10} I d$.

${ }^{11}$ Maritime Delimitation and Territorial Questions Between Qatar and Bahrain (Qatar v. Bahr.), Order, 1999 ICJ Rep. 3, 7 (Feb. 17)

${ }^{12}$ Qatar v. Bahr., 2001 ICJ Rep. at 40, paras. 15-23.

${ }^{13}$ Rules of Court of the International Court of Justice, Rule 67(2).

* ASIL International Law Fellow, 2016. The author served as the first " Vagts Fellow," part of ASIL's international law fellowship program. While not a panelist for the Roundtable, the Vagts Fellow helps implement the Vagts Roundtable program. The author wishes to thanks the Vagts family and ASIL for their support.
} 